Associate Professor Rev. Andrzej Kobyliński, PhD, http://orcid.org/0000-0003-2252-8634

Institute of Philosophy

Cardinal Stefan Wyszyński University

in Warsaw

\title{
Ethical and Legal Aspects of Using the Abortion Pill RU-486 in Italy in the Years 2020-2021
}

\author{
Aspekty etyczno-prawne stosowania pigułki aborcyjnej RU-486 \\ we Włoszech w latach 2020-2021 ${ }^{1}$
}

https://doi.org/10.34766/fetr.v47i3.875

\begin{abstract}
In some countries, one of the most difficult bioethical challenges of the SARS-CoV-2 coronavirus pandemic has been a sharp rise in the number of chemical abortions performed in hospitals, outpatient clinics, or at home. Limited access to medical services at public and private healthcare facilities and the development of telemedicine have resulted in the practice of chemical abortion having largely moved from hospitals and clinics to the home. Chemical abortion is a method used only in the early stages of pregnancy, i.e. up to 7-9 weeks. The first stage of abortion involves taking RU-486, a pill containing a preparation called Mifepristone which kills the newly conceived life in the mother's womb. The second stage of chemical abortion involves the use of a preparation called Misoprostol, which leads to the expulsion of the dead embryo from the woman's body. The main goal of the article is to analyze the ethical and legal dispute in Italy in the years 2020 and 2021 concerning new ways of using the abortion pill RU-486. In August 2020, the Italian Ministry of Health decided that chemical abortion - performed using the medical preparation RU-486 - should not be practiced at hospital gynecological and obstetric wards, but in day hospitals, without the requirement of hospitalization for women performing such abortions. Analyses carried out in the article show that chemical abortion not only kills the life of a human embryo, but in some cases may also be dangerous to the life and health of the mother. The liberalization of chemical abortion in Italy has led to an increase in the number of unborn children who are aborted, as it facilitates access to this type of abortion and makes it a procedure that is largely self-administered at home. The Italian dispute over home abortion and the RU-486 pill is linked to other serious bioethical debates that are currently taking place in many countries around the world.
\end{abstract}

Keywords: bioethics, chemical abortion, pharmacological abortion, RU-486, medical ethics

Abstrakt: W niektórych krajach jednym $\mathrm{z}$ najtrudniejszych wyzwań bioetycznych pandemii koronawirusa SARS-CoV-2 jest gwałtowny wzrost liczby aborcji chemicznej przeprowadzanej $w$ szpitalach, w przychodniach lub $\mathrm{w}$ warunkach domowych. Ograniczony dostęp do usług medycznych $\mathrm{w}$ placówkach publicznej i prywatnej służby zdrowia oraz rozwój telemedycyny doprowadziły do tego, że praktykowanie aborcji chemicznej przeniosło się w dużym stopniu ze szpitali i przychodni do domu. Aborcja chemiczna jest metodą stosowaną tylko we wczesnym okresie ciąży, tj. do 7-9 tygodnia. Pierwszy etap zabiegu aborcyjnego polega na przyjęciu tabletki RU-486, która zawiera preparat o nazwie Mifepriston powodujący uśmiercenie nowopowstałego życia w łonie matki. Drugi etap aborcji chemicznej polega na zastosowaniu preparatu o nazwie Mizoprostol, który doprowadza do wydalenia martwego embrionu z organizmu kobiety. Głównym celem podjętych w artykule rozważań jest analiza sporu etyczno-prawnego we Włoszech w latach 2020-2021, który

1 Polska wersja: https:/ / stowarzyszeniefidesetratio.pl/Presentations0/2021-3-Koby.pdf 
dotyczy nowych form stosowania pigułki aborcyjnej RU-486. W sierpniu 2020 r. włoskie Ministerstwo Zdrowia podjęło decyzję, że aborcja chemiczna - przeprowadzana przy użyciu preparatu medycznego RU-486 - nie powinna być praktykowana na szpitalnych oddziałach ginekologicznopołożniczych, ale $\mathrm{w}$ placówkach funkcjonujących w trybie dziennym (day hospital), bez obowiązku hospitalizacji dla kobiet dokonujących tego rodzaju aborcji. Przeprowadzone w artykule analizy wykazały, że aborcja chemiczna nie tylko uśmierca życie ludzkiego embrionu, ale w niektórych przypadkach może być także niebezpieczna dla życia i zdrowia matki. Liberalizacja aborcji chemicznej we Włoszech spowodowała wzrost liczby abortowanych nienarodzonych dzieci, ponieważ maksymalnie ułatwia dostęp do tej procedury medycznej, czyniąc z tego rodzaju aborcji zabieg realizowany $\mathrm{w}$ dużym stopniu samodzielnie $\mathrm{w}$ domu. Włoska dyskusja dotycząca aborcji domowej i pigułki RU-486 łączy się z innymi poważnymi debatami bioetycznymi, które są obecnie prowadzone w wielu krajach świata.

Słowa kluczowe: bioetyka, aborcja chemiczna, aborcja farmakologiczna, pigułka RU-486, etyka medyczna

\section{Introduction}

One of the very important consequences of the SARS-CoV-2 coronavirus pandemic is the emergence of new bioethical issues which have become an extremely difficult challenge for broadly understood medical ethics and social ethics. New moral problems include the need to define relevant criteria for patients' access to intensive care in life-threatening situations and insufficient number of hospital beds or ventilators, the way of bidding farewell to the bodies of those who died of COVID-19, or the need to develop fair rules for access to appropriate vaccines for all people internationally (Refolo, Sacchini, Spagnolo, 2020).

In some countries, one of the most difficult bioethical challenges of the pandemic has been a sharp rise in the number of chemical abortions performed in hospitals, outpatient clinics, or at home. Limited access to medical services at public and private healthcare facilities and the development of telemedicine have resulted in the practice of chemical abortion having largely moved from hospitals and clinics to the home. Since 2020, in countries such as the United States, Canada or the United Kingdom, some gynecologists have increasingly started writing out prescriptions for RU-486 abortion pills to pregnant patients on demand, the pills being then sent by medical staff to the patients' homes. Telemedicine has created entirely new possibilities, allowing doctors to direct the administration of medicines and medical preparations via a webcam. The advocates of this way of practicing chemical abortion argue that it is safer for women's lives and health, as limiting their contact with the hospital during the pandemic protects them from infection with the coronavirus (Lattarulo, 2021; Rotili, 2020; Spagnolo, 2020b).

One country where new forms of chemical abortion have led to a very difficult bioethical debate is Italy. In the summer of 2020, the Italian Ministry of Health announced that chemical abortion - performed using the medical preparation RU-486 - should not be practiced at hospital gynecological and obstetric wards. Health Minister Roberto Speranza decided that such abortions should be carried out in dispensaries and one-day outpatient 
clinics. Under the new guidelines provided by the Italian Ministry of Health, a woman undergoing a chemical abortion receives the RU-486 pill at a healthcare facility and after half an hour from taking the preparation goes back home, where the human embryo is then aborted. The new regulations have sparked a heated public debate in Italy over fundamental philosophical, ethical and bioethical issues.

The main goal of the article is to analyze the ethical and legal dispute in Italy concerning new ways of using the abortion pill RU-486. The study will primarily analyze publications from the years 2020-2021 relating to this important bioethical dispute. The intended cognitive achievement is to define the basic ethical principles that should be used in the evaluation of various forms of chemical abortion. Clarification of such criteria is extremely important not only in Italy, but also in Poland and many other countries, as modern methods of chemical abortion are now increasingly replacing traditional surgical abortion on a global scale (Kućko, 2019).

\section{Characteristics of chemical abortion}

Since the late 1980s, surgical abortion has been replaced by new forms of chemical abortion, also known as medical or pharmacological abortion. Revolutionary changes in the way abortions are performed have been brought about by a chemical preparation called Mifepristone, commonly known as RU-486 or the "month after" pill. It was created by the French scientist Étienne-Émile Baulieu at the Roussel Uclaf laboratory in Romainville in 1980. "In the country on the Seine, the preparation was introduced into pharmacies in 1988. By now, the pill has been approved for marketing in dozens of countries around the world, including Australia, China, Estonia, Finland, France, Spain, India, Germany, United States, Sweden, United Kingdom" (Kobyliński, 2017: 80). The preparation developed by the French scientist is the most widely known agent used for performing chemical abortions today. In many countries, the chemical preparation RU-486 is officially called the abortion pill. In some scientific papers and publications, chemical abortion is also referred to as "DIY" abortion (Klein, Raymond, Dumble, 2013; Spagnolo, 2020a).

Mifepristone is responsible for blocking the female pregnancy hormone progesterone and stopping the development of the human embryo. Pharmacological abortion is a method used only in early pregnancy, i.e. up to 7-9 weeks. The first stage of abortion involves taking the RU-486 pill which contains 200, 400 or 600mg Mifepristone. The use of this abortive agent inhibits the development of pregnancy and results in killing the newly conceived life in the mother's womb. The second stage of chemical abortion consists in the administration of a preparation called Misoprostol. It is a synthetic analogue of prostaglandin E1, also used in many countries in the prevention and treatment of gastric ulcers. Misoprostol is manufactured, among others, by the American pharmaceutical company Pfizer/Pharmacia 
under the trade name Cytotec. If after taking the "month after" pill, the human embryo is not expulsed, three days after taking RU-486 the woman should take a Misoprostol pill which results in removing the conceived child who has been killed from the mother's body (Morresi, Roccella 2010).

Misoprostol acts by provoking uterine contractions that lead to the expulsion of the dead embryo. Two weeks after taking the preparation it is advisable to visit a gynecologist in order to make sure that there are no remains of the dead embryo in the uterus. Studies in some countries show that $5-8 \%$ of women who have had a chemical abortion also need to undergo surgery to remove embryonic remains. It is worth emphasizing that the RU-486 pill is a typical abortifacient. If this medical preparation is used at 7-9 weeks of pregnancy, then the unborn child who is being killed already has a beating heart and a functioning brain. The baby already displays first nerve reflexes as its muscles and skeleton are being formed. Scientific studies stress that the abortion pill has an efficacy of $93-95 \%$, which means that in about $5-7 \%$ of cases the mother must undergo surgery to finish the abortion procedure or stop a major bleeding (Kobyliński, 2017).

\section{The bioethical revolution of 2020}

On 12 August 2020, the Italian Ministry of Health published new rules for performing chemical abortion using RU-486. Relevant regulations are contained in a special circular entitled "Guidelines for voluntary termination of pregnancy using Mifepristone and prostaglandins." A few days earlier, on August 8, Health Minister Roberto Speranza announced the document's publication on Facebook and Twitter as follows: "The new guidelines, based on scientific evidence, provide for voluntary termination of pregnancy using the pharmacological method in day hospitals up to week 9. This is an important step forward in full compliance with Law 194, which is and remains a civilization norm" (Poggio, 2020). Law 194, referred to in the post published by the Italian Minister of Health, is the abortion law adopted in the country on the Tiber in 1978, commonly referred to as Law 194 or Law 194/1978.

Until the new guidelines were published, the practice of chemical abortion using RU486 in Italy had been regulated by the law of 2010. Thus, the new law of August 2020 amends the guidelines of 2010 which provided for a three-day hospitalization of women performing chemical abortions. This means that under the old regulations hospitalization was mandatory - no pharmacological abortion was allowed in day hospitals. Medical abortion could be performed up to the $7^{\text {th }}$ week of pregnancy. The 2010 guidelines specified that the risks associated with pharmacological abortion could only be compared with those involved in a surgical abortion if the pregnancy was terminated in a hospital. Even if it might appear that the chemical abortion procedure is less invasive than surgical abortion, it does not mean 
that no complications may develop after the former which threaten the health and life of the mother and are difficult to predict.

The Italian Law 194/1978 provides that the entire abortion process must be carried out in hospitals or facilities specified in the regulations. As a result, no abortion may be performed at home. It is worth noting, however, that in the 1970s, when the Italian abortion law was enacted, chemical abortion did not yet exist, and the most commonly practiced form of abortion was a surgical procedure. At the beginning of this century, along with the approval of the RU-486 pill for marketing in Italy, the Ministry of Health resolved to develop appropriate legislation, which was not present in the 1978 Law. Relevant guidelines were published in 2010. The provision about a three-day hospitalization for women who terminate pregnancy using the chemical procedure was dictated by the fact that taking abortion pills may lead to a number of dangerous complications.

The opinion of the Supreme Health Council (Consiglio superiore della Sanità) which accompanied the ministerial guidelines of 2010 explicitly stated the medical view that women who have taken the RU-486 pill should not be discharged from hospital on request to go home before the end of the entire process of chemical abortion in order to avoid a situation where the embryo's expulsion from the mother's organism does not take place in hospital, but at home, entailing a risk to the woman's health. The Supreme Health Council stressed in their opinion that a woman should not be left alone with her physical and mental suffering. The side effects of the abortion pill have been widely described in scientific literature: abundant and prolonged bleeding, fainting fits, increased pressure, nausea, vomiting, abdominal pain and cramps, endometriosis, so-called incomplete abortion. As for the last adverse effect, a percentage of women in Italy who have taken RU-486 need to be hospitalized in order to complete the chemical abortion procedure by way of a surgery (Kobyliński, 2018).

It is worth noting that in the years 2010-2020 there was no uniform, nation-wide model for the use of chemical abortion in the country on the Tiber, as the authorities of a number of regions, exercising their political autonomy and articulating their independence from the central government in Rome, did not respect the 2010 guidelines of the Ministry of Health. In regions such as Emilia Romagna, Lazio, Liguria and Lombardy, local authorities authorized the administration of RU-486 in day hospitals. The Toscana region, on the other hand, went even further and permitted the use of abortion pills also in dispensaries and outpatient clinics. Under the new rules, introduced in some regions of Italy before 12 August 2020, a woman who took the RU-486 pill remained in a day hospital, dispensary or outpatient clinic for about half an hour until the first medical consultation. She then went home and returned after 48 hours to take Misoprostol, which causes expulsion of the dead embryo from the mother's womb. Consequently, the new guidelines of August 2020 may be said to have legalized the practice of chemical abortion already in place in some regions of 
the country on the Tiber. The real novelty of this document was the extension by two weeks of the period during which pharmacological abortion is permitted.

According to Pino Noia, gynecologist and President of the Italian Association of Catholic Gynecologists and Midwives (Associazione Italiana Ginecologi Ostetrici Cattolici), the first victim of the Italian Minister of Health's decision of August 2020 is honest prenatal science, which is nowhere to be found in the guidelines. According to the President, there are no scientific arguments that justify postponing the use of RU-486 from 7 to 9 weeks. Scientific research unequivocally confirms that the later a woman performs an abortion, the higher the risk of various complications and negative health consequences. Pino Noia categorically states, therefore, that chemical abortion is never simple, painless or safe, contrary to what is claimed by its advocates (Zambrano, 2020). Scientific research confirms that women are more likely to suffer from profuse bleeding after pharmacological abortion than following surgical abortion. The risk of major blood loss is lower in women who have undergone a medical abortion up to the $49^{\text {th }}$ day of pregnancy compared to those who have performed this form of abortion between the $7^{\text {th }}$ and $9^{\text {th }}$ week of pregnancy. This means that moving the time limit to 9 weeks poses a considerable risk to women's health.

\section{Liberalization of chemical abortion from the legal and ethical perspective}

In August 2020, the Italian Ministry of Health published new guidelines after the Supreme Health Council had expressed a favorable opinion on the matter. The Italian Association of Gynecologists and Midwives (Società Italiana Ginecologi e Ostetrici) took exactly the same position as regards the liberalization of chemical abortion. Unfortunately, the Ministry of Health has classified all files of this case, most importantly not publishing any information on the various risks associated with the use of RU-486. Consequently, the general public could not be informed about the "for" and "against" arguments contained in documents prepared by the Supreme Health Council and the Italian Association of Gynecologists and Midwives. Clearly, these were not unanimous decisions. However, as the documents were classified, Italian citizens were unable to familiarize themselves with the position of those scientists who were opposed to issuing a positive opinion on the liberalization of chemical abortion.

Critics of the new guidelines believe that the public has the right to information concerning this case. Moreover, they argue that the new rules violate the abortion law that had been in force in the country on the Tiber for more than 40 years. Those challenging the new guidelines point out that since liberalization of using RU-486 concerns the very essence of Law 194/1978, the Ministry of Health may not implement such changes by publishing its decision in a circular, but that there should be a serious parliamentary debate on the matter. This position was expressed, among others, by Alberto Gambino, President of the Science \& 
Life Association, one of Italy's strongest pro-life organizations. In his view, the ministerial guidelines have no legal force and are not binding on regional authorities, which have separate legislative powers in the area of healthcare.

Alberto Gambino notes that Law 194 provides for a procedure which begins with an information phase in order to address the causes that may have led to an application for abortion. The procedure is then continued if serious indications are found to justify termination of pregnancy. Except for medical assistance provided in accordance with the protocol set out in Law 194/1978, abortion is and remains a criminal offence. The President of the Science \& Life Association argues that the introduction of a new medical protocol concerning chemical abortion cannot be effected by way of an ordinary ministerial circular. He believes that any amendments to the 1978 Abortion Law must be introduced by way a parliamentary debate, which is the only democratic tool that allows the whole of society, through its representatives, to present their position (Morresi, Roccella, 2020).

Another legal issue that has emerged in the debate around the Ministry of Health's new guidelines concerns the autonomy of regional authorities from the central government in Rome when it comes to the management of Italy's public healthcare. It is part of a major dispute that has been going on for many years in the country on the Tiber over granting greater political and financial independence to individual regions. In the context of this dispute, authorities of the Piedmont region decided to reject the guidelines developed by Minister Roberto Speranza. In the autumn of 2020, the Piedmont authorities commissioned expert legal opinions which clearly show that the liberalization of chemical abortion introduced by the Ministry of Health's guidelines - is incompatible with the Italian Abortion Law 1978. Consequently, RU-486 is used in this region only when the woman performing an abortion is hospitalized, rather than in day hospitals, clinics, or at home. Moreover, the local authorities have significantly expanded the various forms of assistance offered to pregnant women who are considering killing their unborn children, so that they change their minds and give birth to new human beings (Morresi, Roccella, 2020).

On 14 August 2020, the Pontifical Academy for Life spoke on the new guidelines of the Italian Ministry of Health. In a special note they stressed that the new solutions adopted in the document should be revised. "The first deals with removing the requirement that the full protocol of chemical abortions be performed on an inpatient basis (but in reality that requirement has been often by-passed). Now, the drugs can be administered or furnished to an outpatient, followed by the expulsion of the dead embryo from the mother's womb after she has returned home. If the mother's concomitant physical pain becomes too intense or she experiences complications, particularly excessive bleeding, a dedicated emergency healthcare facility is to be available. The second change extends the time within which a chemical abortion may be performed - up to nine completed weeks of gestational age (63 days) instead of the earlier seven. The surgery can therefore take place at a more advanced 
stage of pregnancy, when uncertainty and risk may be greater" (Pontifical Academy for Life, 2020).

The authors of the Vatican document state that the new guidelines of the Italian Ministry of Health relegate chemical abortion even further to the private sphere. On the other hand, it is important to ensure that the intense emotional reactions caused by pregnancy are experienced more broadly and more fully, especially at the beginning of pregnancy. The particular delicacy of this moment is due to the transformation of becoming a mother (and parents), when the presence of the conceived child puts into question precisely the most personal aspects: body, space, time, etc. "Allowing an abortion, with all the problems it creates, to take place in the home means distancing abortion even further from the web of social relations and from the world of shared responsibility - precisely the web and world that Law 194 attempted to salvage. It might be easy to argue - and with some good reasons - that the hospital environment is not necessarily the best place to provide the intended accompaniment and support or that in any event they come into play only during the lead-up to a decision to terminate a pregnancy. But precisely for this reason it is necessary not to give up searching for more suitable methods and tools to bring about a shared project: accompaniment and support for the nascent and conceived life, and for families, remain the test bench for an attentive and caring society that knows how to build its future with wisdom and foresight" (Pontifical Academy for Life, 2020).

The position presented by the Pontifical Academy for Life has been criticized by a group of conservative Catholic intellectuals who are members of the Advisory Board of the Pontifical Theological Institute "John Paul II" for Marriage and the Family Sciences. They expressed their concern and strong dissatisfaction with the position of the Pontifical Academy for Life. In their view, the document of the Vatican dicastery uses ambiguous language in its criticism of the new Italian guidelines on chemical abortion, completely disregarding the moral condemnation of abortion. The document of the Pontifical Academy for Life does, in fact, evoke the provision of the Law of 1978 which states that the Italian State, by guaranteeing the right to conscious and responsible procreation, recognizes the social value of motherhood and protects human life from its beginning. Even though the legislator sets out the conditions under which termination of pregnancy is legal, it also states that abortion cannot be regarded as a tool of birth control. Under the Law, family counsellors should support a woman who is considering termination of pregnancy by informing her of all aspects of this medical procedure and seeking, together with her, to remove those causes which may lead her to terminate pregnancy. Researchers at the Pontifical Theological Institute "John Paul II" for Marriage and the Family Sciences also say that the Abortion Law of 1978 is one of the most important causes of the major demographic crisis already faced by the country on the Tiber (Negrotti, 2020; Ognibene, 2020). 
On August 19, 2020, L'Osservatore Romano published a very important article entitled "Women's Health and the Risks of RU-486." Its author is Giuseppe Noia, professor of prenatal medicine at the Catholic University of the Sacred Heart in Rome. He believes that the decision of the Italian Ministry of Health to extend the time limit for taking the RU-486 abortion pill from 7 to 9 weeks and leave out mandatory hospitalization of the women raises some very profound and difficult questions about the psychological, social, medical and scientific aspects of such decisions. Noia says that abortion continues taking its toll on innocent victims everywhere and devastates the lives of many women; for this reason, the decision to extend the abortion practice in the country on the Tiber is extremely disturbing, increasing the chances of killing children who, by their existence, only ask to be allowed to come into this world (Noia, 2020).

The Catholic University of the Sacred Heart in Rome professor disagrees with the supporters of RU-486 who claim that chemical abortion is simple, painless and safe. He says that the alleged simplicity of taking the pill, without any follow-up medical examination to monitor the abortion and its possible complications, is nonsensical and profoundly devastating at the psychological level for the relationship that develops between the mother and the child. From the very beginning of pregnancy, the woman is aware of the child's existence, and this awareness is independent of the baby's dimensions in grams and centimeters; rather, it is proportional to the child's "presence." The notion that removing a small embryo is tantamount to a minor injury is scientifically untrue. Noia argues that pharmacological abortion tries to leave unsaid the scientific truth about this biological, immunological, hormonal and psychodynamic relationship that is formed between the embryo, or child, and its mother from the very moment of conception. With the development of medical sciences we now know that from the fourth week of pregnancy the embryo begins to develop a whole series of patterns at the sensory, gustatory and olfactory level, also through its relationship with the mother. A cellular exchange begins between the child's organism and the mother's body. The child sends stem cells to the mother, which, passing through the placenta, arrive with the blood at pathological areas in her body to cure them: the fetus is in fact its "mother's doctor." For her part, the mother develops a strong and intimate perception of the child's presence, supporting it with oxygen and dietary supplements: this mutual relationship is called "maternal-fetal symbiosis" and is a wonderful mystery which science is now able to study and begin to understand (Noia, 2020).

The Catholic University of the Sacred Heart in Rome professor rejects the claim that termination of pregnancy with RU-486 is painless. On the physical level, it is associated with very painful cramps. On the psychological level, it generates hyperactivity in the woman, for it is she who must take the pill, becoming the actor, protagonist and observer of her child's agony and the hemorrhagic episodes which may appear anywhere and anytime for up to two weeks, without any warning, in many cases exposing the woman to the devastating 
experience of seeing the embryo expelled from her body. Chemical abortion is associated with the risk of many health complications. Moreover, after taking the abortion pill, pregnancy may still continue. This probability increases the later in the pregnancy the abortion pill is taken. Continuation of pregnancy after chemical abortion is doubly devastating both psychologically and physically, because if the woman revises her choice and wants to continue the pregnancy, she will face another problem as the use of an abortion pill may cause malformations in the fetus. On the other hand, if she wanted to repeat the abortion procedure, she would have to use medical preparations in higher doses, with an even more serious risk to her own health (Noia, 2020; Verlicchi, 2020).

\section{Summary}

The social discussion in Italy over the liberalization of chemical abortion is an important part of the contemporary bioethical debate, which is becoming increasingly global in dimensions. Analyses carried out in this article substantiate several important research conclusions.

Firstly, the new rules on the use of RU-486 adopted in Italy on 12 August 2020 are yet another step towards the trivialization of killing human life at the initial stage of its development. The decision taken by the Italian Ministry of Health will contribute to an increase in the number of aborted children, as it facilitates women's access to chemical abortion and makes it a medical procedure performed at home largely on their own. Removing the requirement of hospitalization and postponing the time limit on using the abortion pill from 7 to 9 weeks of pregnancy seriously increases the risk of various complications that accompany this medical procedure and are well documented in scientific literature. One must not forget that in some cases the RU-486 pill not only kills the human embryo, but may also be harmful to the woman who takes it. Mifepristone not only destroys new human life at the initial stage of its development, but may also be dangerous to the life and health of the woman.

Secondly, the recent liberalization of chemical abortion in Italy testifies to the profound world-view changes that have taken place in its society over the last few decades. 2021 marked the $40^{\text {th }}$ anniversary of the referendum held in the country on the Tiber on 17 May 1981 which concerned amendments to Law 194/1978 making abortion legal up to the third month of pregnancy. In the spring of 1981, Italians went to the polls to vote on two referendum proposals that sought to amend the abortion law in force at the time. The proposal made by left-wing groups aimed at completely liberalizing abortion, while organizations fighting to protect conceived life proposed to place restrictions on abortion practices (Scandroglio 2021). As many as $79.43 \%$ of the population of the Italian Republic went to the referendum polls. Both proposals were rejected: $88.42 \%$ of voters said "no" to the 
liberalization of the Abortion Law of 1978, while $68 \%$ of Italian citizens said "no" to the tightening of abortion regulations. Consequently, the referendum did not result in amending Law 194/1978. Forty years after those events, it must be concluded that Italian society has become much more pro-abortion. While in 1981, abortion was still a moral and social problem in the country, in the collective consciousness of the Italian society it has now become only an individual, private matter of the woman (Kobyliński, 2020).

Thirdly, changes in the use of RU-486 in Italy have combined with the liberalization of access to EllaOne, called the "five days after" pill. In October 2020, the Italian Medicines Agency decided that it would no longer be necessary to have a medical prescription for EllaOne, a drug used in so-called emergency contraception up to five days after intercourse. The medical preparation EllaOne has both contraceptive and abortive effects. Given that the pill may also act as an abortifacient, the manner in which it is administered should fall within the legal framework of Act 194/1978, which requires an interview at an outpatient clinic or with a trusted doctor, followed by the issuance of a medical certificate. In the case of minors, the Law requires an opinion of the parents or legal guardians. The solution adopted in Italy in the autumn of 2020 leads to a profound trivialization of contraception and abortion: a minor may simply go to the pharmacy and buy an EllaOne pill. There is no doubt that the liberalization of access to this preparation significantly increases the number of crypto-abortions in the country on the Tiber (Kućko, 2020; Sartea, 2020).

Fourthly, the dispute over chemical abortion has revealed profound doctrinal changes that have occurred among Italian Catholics in recent years. Fewer and fewer philosophical and theological arguments are present in statements by representatives of the Catholic Church in the country referring to ethics, natural law, the criteria for the beginning of human life, the moral evil of abortion, etc. Most often, they are dominated by legal arguments relating to the implications of Law 194/1978. Among Catholics in Italy, acquiescence to killing life at the initial stage of its development is becoming more and more widespread. A new understanding of conscience and natural law is also beginning to prevail. As a result, conscience is now understood as an act of unconditional will, thus being granted a primacy which it cannot have unless each of us becomes a "law unto ourselves." Once conscience is stripped of its reference to natural law, and each individual becomes radically autonomous and represents "a law unto themselves", one of the consequences of such philosophical and theological changes is acquiescence to the legalization of various forms of chemical and surgical abortion.

Fifthly, the Italian discussion concerning RU-486 is related to other serious bioethical debates that are currently taking place in many countries around the world. One such country is France. In the country on the Seine, a fierce parliamentary debate over amendments to the Bioethical Law has been going on since 2019. One of the proposed changes concerns the possibility of creating human-animal chimeras. Such interspecies 
embryos would be used in laboratories for various medical experiments and clinical trials. In addition, the law provides for the possibility of experimenting on artificially created and unused human embryos, for example by creating transgenic, or genetically modified, embryos. Embryos used for research would have to be killed by the $14^{\text {th }}$ day of their development at the latest. The research, theoretically carried out in order to gain a better understanding of the causes of miscarriages and genetic diseases, would have to be approved by the governmental Biomedical Agency, but there is no doubt that the bill would open the door wide for genetic eugenics and transhumanism. Should the authorities in Paris grant their consent to mixing human and animal cells, this would mean crossing yet another Rubicon in the modern biotechnological revolution (Dzwonkowska, 2020; Waleszczyński, 2019). The creation of human-animal chimeras, manipulation of human embryos, and treatment of human life at an early stage of its development as mere laboratory material are all manifestations of the progressive dehumanization and objectification of human existence.

\section{Bibliography:}

Dzwonkowska, D. (2020). Environmental Vices as Ethical and Anthropological Roots of the Environmental Crisis, Studia Ecologiae et Bioethicae, 18 (5), 171-180, https://doi.org/10.21697/seb.2020.18.5.15.

Klein, R., Raymond, J., Dumble, L. (2013). RU 486: Misconceptions, Myths and Morals, North Geelong: Spinifex Press 2013.

Kobyliński, A. (2017). Bezpieczna aborcja? Etyczne aspekty stosowania pigułki aborcyjnej RU-486, Studia Ecologiae et Bioethicae, 15 (4), 79-89, https://doi.org/10.21697/seb.2017.15.4.08.

Kobyliński, A. (2018). Aborcja chemiczna w domu? Nowa forma stosowania pigułki aborcyjnej RU-486 we Włoszech, Studia Ecologiae et Bioethicae, 16 (1), 15-36, https://doi.org/10.21697/seb.2018.16.1.02.

Kobyliński, A. (2020). The Philosophical Arguments in the Dispute over Artificial Reproduction in Italy in the Years 2004-2014, Studia Ecologiae et Bioethicae, 18 (5), 143 154, https://doi.org/10.21697/seb.2020.18.5.13.

Kućko, W. (2019). Dylematy etyczne dotyczące badań prenatalnych prowadzonych w Polsce, Teologia i Moralność, 14(1), 121-138, https:// doi.org/10.14746/tim.2019.25.1.8.

Kućko, W. (2020). W służbie społeczeństwu i rodzinie - współczesne ujęcia etyki farmaceutów, (in:) W. Nowak, K. Szalonka (red.), Zdrowie i style życia. Determinanty długości życia, 297-313, Wrocław: E-Wydawnictwo. Prawnicza i Ekonomiczna Biblioteka Cyfrowa, http://doi.org/10.34616/23.20.123.

Lattarulo, P. (2021). Bioetica e dentologia professionale, Columbus: McGraw-Hill Education.

Morresi, A., Roccella, E. (2010). La favola dell'aborto facile. Miti e realtà della pillola RU-486, Milano: Franco Angeli Edizioni. 
Morresi, A., Roccella, E. (2020). Aborto anche nei consultori? Ma così si va oltre la legge 194, Avvenire, 195, 8.

Negrotti, E. (2020). Così si lasciano le donne sole, Avvenire, 189, 7.

Noia, G. (2020). La salute delle donne e i rischi della RU-486, L'Osservatore Romano, CLX (188), 3.

Ognibene, F. (2020). La RU-486, una conquista? Così si ignora il concepito, Avvenire, 208, 12.

Poggio, D. (2020). Strappo sull'aborto (in un tweet), Avvenire, 189, 6.

Pontifical Academy for Life, (2020). Note About the Announcement of New Guidelines On Pharmacological Abortion in Italy:

http://www.academyforlife.va/content/pav/en/the-academy/activityacademy/note-guidelines-on-pharmacological-abortion-in-italy.html (Access: 21.06.2021).

Refolo, P., Sacchini, D., Spagnolo, A.G. (2020). Pandemic emergency triage: about the risks of a trolleyology, Medicina e Morale, 69 (4), 471-482, https://doi.org/10.4081/mem.2020.852.

Rotili, S. (2020). COVID-19 Legacy. SARS-CoV-2 clinical trials, vaccines trials and bioethics, Milano: Streetlib.

Sartea, A. (2020). EllaOne „libera”, farmacisti in allarme, Avvenire, 293, 21.

Scandroglio, T. (2021). Aborto, 40 anni dopo: una sconfitta che interroga l'oggi, La Nuova Bussola Quaotidiana, 17.05.2021: https://www.lanuovabq.it/it/aborto-40-anni-dopouna-sconfitta-che-interroga-loggi (Access: 21.06.2021).

Spagnolo, A.G. (2020a). RU486: è solo una questione medico-farmacologica? Medicina e Morale, 69 (3), 275-279, https:// doi.org/10.4081/mem.2020.702.

Spagnolo, A.G. (2020b). Safety and bioethics in the days of COVID-19. Medicina e Morale, 69 (1), 5-9, https:// doi.org/10.4081/mem.2020.604.

Verlicchi, D. (2020). Tra dolore e solitudine il mio aborto con la pillola, Avvenire, 191, 12.

Waleszczyński, A. (2019). Między troską a sprawiedliwością - Virginii Held poglądy na wspólnotę polityczną, Roczniki Filozoficzne, 67 (3), 115-135, https://doi.org/10.18290/rf.2019.67.3-6.

Zambrano, A. (2020). Segreti e verità taciute sui rischi della pillola killer: il ministro sapeva, La Nuova Bussola Quotidiana, 11.08.2020: https://www.lanuovabq.it/it/segreti-everita-taciute-sui-rischi-della-pillola-killer-il-ministro-sapeva (Access: 21.06.2021). 